\title{
MODELLING EFFICIENCY IN EDUCATION How are European countries spending their budgets and what relation between money and performance
}

\author{
Isabel Flores \\ ISCTE-IUL, Lisbon, Portugal
}

\begin{abstract}
Aggregate expenditure in education was compared to PISA's scores (2012) as a mean of understanding how money link to performance. We analysed global education expenditure, teachers' pay, class size and number of teaching hours, infrastructure and teaching resources investment in European countries. Four groups of efficiency / effectiveness are proposed based on the combination of expense versus results. The author concludes that the most effective countries are Poland, Slovenia and Czech Republic, as they achieve top results with moderate investment. There are also some countries where desired score is achieved, though a lot of money is being spent. The remaining countries do not achieve desired scores and therefore are neither efficient nor effective, though Sweden and Norway spend a lot of money for very poor results, and are therefore the most inefficient countries.
\end{abstract}

Keywords: education efficiency, public expenditure, PISA scores, education effectiveness.

Resumo A despesa agregada na educação foi comparada com os resultados no teste PISA (2012) como forma de compreender a ligação da despesa em educação com o desempenho dos alunos. Analisou-se a despesa agregada em educação, o ordenado dos professores, o tamanho das turmas e o número de aulas lecionadas, assim como o investimento em infraestruturas e recursos de ensino em países da Europa. Quatro grupos de eficiência / eficácia são propostos, baseados na combinação despesa versus resultados. Conclui-se que os países mais eficientes são a Polónia, a Eslovénia e a República Checa, dado que atingem resultados de topo com um investimento moderado. Existem igualmente outros países onde os resultados são muito bons, mas no entanto o nível de despesa é muito elevado. Os restantes países não alcançam os resultados desejados, donde que não são nem eficientes nem eficazes. De notar, no entanto, que a Suécia e a Noruega são particularmente ineficientes porque têm uma enorme despesa em educação e alcançam resultados médios muito baixos.

Palavras-chave: eficiência da educação, gasto público, resultados do PISA, eficácia da educação.

Résumé Une analyse de la dépense globale en matière d'éducation a été comparée avec les résultats dans le test PISA (2012) comme méthode pour comprendre le rapport entre les dépenses en matière d'éducation et la performance des élèves. Nous avons analysé les dépenses globales en éducation, le salaire des enseignants, la dimension des classes et le nombre de classes enseignées, ainsi que l'investissement en ressources d'infrastructure et d'enseignement dans les pays européens. Quatre groupes d'efficacité sont proposées sur la base de la combinaison des résultats par rapport aux dépenses. Il a été conclu que les pays les plus efficaces sont la Pologne, la Slovénie et la République Tchèque, car ils ateignent les meilleurs résultats avec un investissement modéré. Il y a aussi des pays où les résultats sont très bons mais le niveau des dépenses est très élevé. Les autres pays n'ont pas atteint les résultats souhaités et donc ne sont pas efficaces. Notez, cependant, que la Suède et la Norvège sont particulièrement inefficaces parce qu'ils ont une énorme dépense en éducation pour atteindre de très faibles résultats moyens.

Mots-clés: $\quad$ efficacité en éducation, dépenses publiques, résultats du PISA.

Resumen Un análisis del gasto agregado en la educación se comparó con los resultados del programa PISA (2012) como una manera de entender la conexión de los gastos en la educación al rendimiento del estudiante. Se analizó el gasto agregado en la educación, el salario de los profesores, el tamaño de las clases y el número de clases que se imparten, así como la inversión en infraestructura y recursos de enseñanza en los países europeos. Se proponen cuatro grupos de eficiencia / eficacia basada en la combinación frente a los resultados de gastos. Se concluyó que los países más eficientes son Polonia, Eslovenia y República Checa como lograr los mejores resultados con una inversión moderada. También hay otros países en los que los resultados son muy buenos, sin embargo, el nivel de gasto es muy alto. Otros no logran los resultados deseados de la que no son ni eficiente ni 
eficaz. Tengase en cuenta, sin embargo, que Suecia y Noruega son particularmente ineficientes porque tiene un enorme gasto en educación y logra resultados promedios muy bajos.

Palabras-clave: eficiencia de la educación, gasto público, los resultados de PISA, la eficacia de la educación.

\section{Introduction}

This paper has the objective of throwing some light on the important subject of education efficiency. Measuring both input and output in social investment is always delicate and far from being straightforward, though it is vital to a well-oiled system.

This area brings economics and policy together in giving attention to the form how data can be used and modelled to help better and more accurate decisions for the system. In a world with finite resources, knowing the price of educating citizens, and how to better use the investment to maximize the outcome is a central question to politicians, managers, parents and every taxpayer. A more efficient system does not need to be feared as disinvestment in education and worst service for citizens. Welch (1998) argues that historically "efficiency" means blind cuts to education. Politicians, economists, school managers can not turn a blind eye on where to spend the money. More money in the system is not, always, a meaning for quality. Efficiency is about choosing the most efficient mix, and deciding in where to invest (Woessmann and Schuetz, 2006).

The amount of money that gets into the system is not always calculated, nor reported. It is hard to have the exact accountancy of values as this is a very big field, and investment tends to extend through long periods of time. Frequently, projects are abandoned without completion, bringing extra pain in the calculation of costs. Lack of transparency in public accounts is another hardship that the researcher has to face, and it is often impossible to trace information backwards in the effort of reconstructing the investment path.

On the output side, there are also difficult answers to solve. In subjects such as the economics of education there has been an intense discussion on what is the final goal of education, and how can we measure school effects. On the one hand, it is well known that family, social, economic and cultural background of each child is determinant for her success (Coleman, 1967). Some systems, that may look inefficient, are just paying the long term price of badly educated parents. As "the children of today are the parents of tomorrow" (Afonso and Aubyn, 2005) education results will also improve, in a ceteris-paribus environment. Universal school access has a major role in increasing equality and in the long term improving results (Lemos, 2013). Despite realising the importance of family background on achievement this variable would be odd to introduce in this model, as there are no significant differences among most countries, except for Portugal which shows, comparatively, very low education background. As shown by Martins and Veiga 
(2010) the differences are more evident when comparing socio-economic indicators, and not as much when only parents' education or parents' occupation come in the model. At country level there seems to be an association between higher level of parents' qualification (or white collar jobs) and better results in Maths, though these differences are harder to spot at an aggregate level as, for example, children of cleaners in some countries outperform children of managers in other countries (OECD, 2014). As the cost of education and other investments are considered in PPPs we are already considering economic differences at aggregate level.

Despite all the above considerations, schools make a big difference in a society, and should be seen as the central point of every public policy (Rodrigues, 2012). Education is a pillar of the economic system, with long term consequences for each and every economy.

The objective of this paper is to bring together education aggregate variables that are related to cost and expenditure, compare those to outcome variables (Maths PISA scores) and observe how countries are organising themselves.

\section{Theory and inspiration}

Adam Smith, back in the XVII century, has pioneered measuring education productivity, inspired on manufacturing processes. Many other economists and social researchers (Hanushek, 1986; Lockheed and Hanushek, 1994; Welch, 1998) have been looking for a productivity function to associate with education.

Education output is difficult to measure due to many non-controllable factors involved in the equation: student individual factors, social circumstances, government priorities, school daily practices among others (Wagstaff, 2011). Input is not also straight forward, though it is possible to tackle purchased inputs such as salaries, infrastructures, teaching resources; it is not obvious how to include motivation and donations of all sorts.

Despite the complexity, progress has been made, and academics have thrived lines of research. Based on the idea of cost-benefit, to tackle the increase in productivity, different lines of policy have emerged. "Productivity in education is concerned with the quantity and quality of outcome that results from a given level of resources" (Rice and Schwartz, 2008).

Hanushek (1986) following the pioneering work of Coleman Report (Coleman, 1967), has developed work on costing education and investigating if money makes a difference to results. At the time, he came to a mixed conclusion suggesting that there was no clear correlation between extra money and better student results. This conclusion spread misunderstandings and was many times used by politicians wanting to reduce budgets. Nevertheless, during the early 2000s many other studies (Baker, 2012; Mccluskey, 2004) have been developed, using better data and more modern analysis techniques to conclude that money does make a difference, especially the goods and services money can buy make a difference. So the important question is: how can we use limited resources wisely? 
Most research end up focusing on teacher both in quality and quantity, as they are seen as a pillar of the system and also account for the greatest share of investment. Recently a group of researchers launched The Efficiency Index (Dolton, Marcenaro-Gutiérrez and Still, 2014) where only two variables are considered as inputs - teacher pay and the number of pupils per teacher. Though the Efficiency Index is an attempt to systematise this concept, it is very narrow scope and can lead to mal-interpretations.

Can schools deliver a better outcome for the same investment? How much will it cost to increase the outcome?

Answering these questions involves knowledge of the productive structure: prices to pay for inputs (salaries, infrastructures...) and the extent to which schools are inefficient. Governments know that money matters (Baker, 2012) though no author has been able to find a direct relation.

Recent research has moved from simple analysis of global amounts to what money can buy - quality of schools' buildings, teacher quality and motivation, class size, among others. Random studies in Tennessee (Hanushek, 2012) have shown that class size matters, though further studies are still needed as it does not work as a magic bullet for results' improvement.

Complex theory has often been called into action as a way to disentangle the variables associated with learning. Education efficiency should be seen as a complex circular system, where funding should generate opportunities for learning; given those opportunities students will learn and show their knowledge on student performance indicators. Those indicators influence future funding decisions.

\section{Question and structure}

The questions underneath the research were: "How efficiently is the money invested in education?"; "Can we spot any pattern of investment that is tailored to better results?"; "Which countries have the best relation - investment, expenditure, results?"; "Can countries copy each other on education efficiency?"

To measure these relations, we used as dependent variable the quantitative indicator given by PISA to work as a proxy of education output. This is one of the few measurements that compare students' knowledge across countries. The relatively small differences among the absolute performance of countries may not heighten real system specificities nor the relation among weak and strong aspects. As we are comparing only European countries the convergence to the middle is natural, as these countries end up not being so different in socio and economic stages of development.

Independent variables were stratified into three big groups:

- How much money comes into the system and how it is spent?

- What is being bought by money and how each of those items influences outcome?

- To which extent investment is properly used by school communities? 
To focus on the quantity of money into the system we used global annual amount per student as presented by OECD's Education at a Glance 2013 (OECD, 2013). All the money values are United States Dollars (USD) and in Parity Purchasing Power (PPPs), in order to facilitate comparison. The distribution of current and capital expenditure were also analysed, and the major differences identified.

The second stage was to describe how money is spent in each European state, what is granted to each resource and also how countries diverge from one another in education expenditure structure. A regression of results to expenditure structure was also developed.

Finally, a clustering model is suggested where groups of countries are formed according to their level of investment, expenditure, qualitative and quantitative results.

\section{Money in education systems}

Funding for education was gathered from OECD's Education at a Glance 2013, ${ }^{1}$ from their chapter B: "Financial and human resources invested in education".

From those indicators, some of greater relevance for the objective of this paper were selected and analysed:

- expenditure on education - per student as a percentage of GDP in PPPs;

- where is the money spent?

- what is the relative cost of teachers' and what is left for other expenses?

How much money does education need?

The amount of money a country spends educating each child is associated with the global richness of that country, here measured in GDP per capita. Figure 1 illustrates this point clearly as it features a linear regression with an $\mathrm{R}^{2}=0.72$, meaning that countries with high GDP invest more than poorer countries. This means that the variance in GDP per capita accounts for $72 \%$ of the variance in education per child budget.

The country with the highest spending per student is Switzerland followed by Norway (with a per student expenditure of 16,000 USD and 14,000 USD), who are clearly outliers spending much more than any other OECD country. On the opposite extreme, there are Hungary and Slovak Republic with three times less expenditure, both around 5000 USD. For this group of countries, the average is 9750 USD. United Kingdom, Netherlands, Spain, Germany and Finland are very near average.

Follows the obvious question: "Is there a connection between money spent per student and their assessment results?" 2

http://www.oecd.org/edu/educationataglance2013-indicatorsandannexes.htm

As already stated the author has opted to use PISA's Math score as a proxy of school outcome.

There is a high correlation with the results in the other tested subjects, Language and Science.

Maths was under special scrutiny in 2012, so the results are broader. 


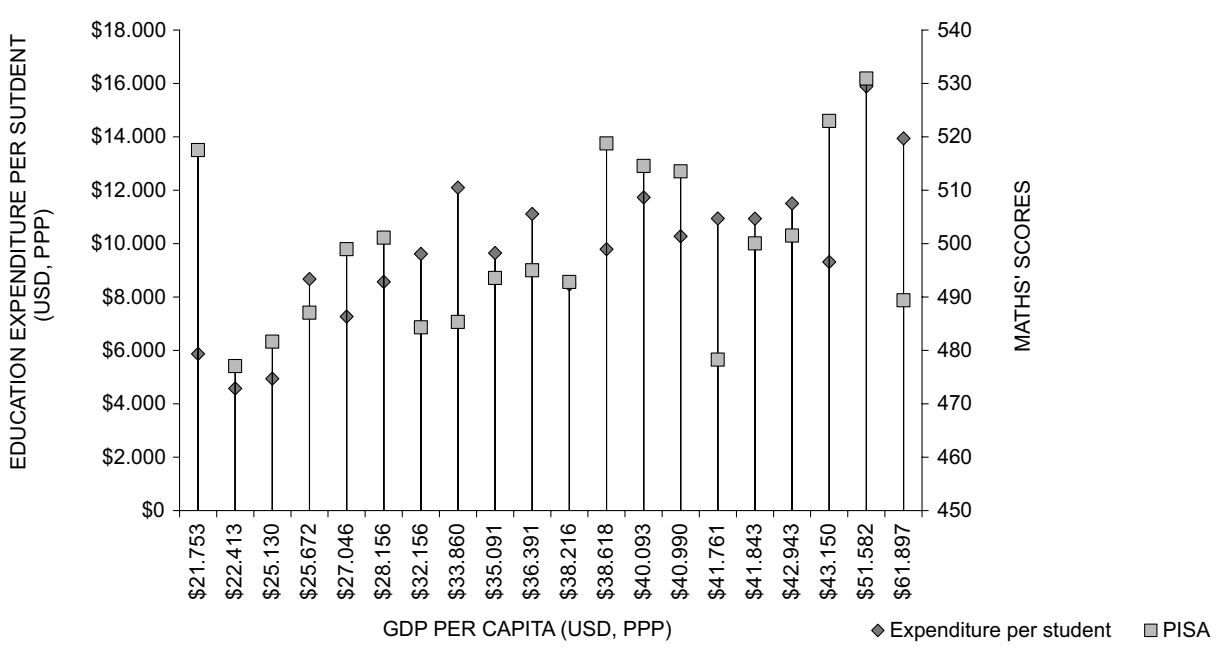

Figure 1 GDP per capita versus education expenditure per student and PISA's Maths Scores Source: OECD, Education at a Glance 2013, and PISA 2012.

A very moderate positive correlation $\left(R^{2}=10.7 \%\right)$ is shown in PISA's average scores to expenditure per student and also to GDP. Countries investing relatively small amounts have achieved very positive results (Poland, Czech Republic and Slovenia), but some countries with enormous investment have scored well below the international average (Norway, Italy, Sweden). The picture is totally mixed and shows that money is certainly important, though it is not a sufficient reason for success. Norway, Italy and Sweden are countries where money is not being used efficiently, while Poland is an example of efficient use of resources.

\section{What money can buy?}

Our next question is: "Where is the money spent and what evidence do we have to analyze the efficiency of expenditure?"

In every country the biggest share of education expenditure is to face current expenses - salaries and daily consumption goods. A very small percentage of expense is left for capital, i.e. for investment in infrastructure, computers and libraries. The countries with the highest relative investment in capital are the United Kingdom, Norway and Netherlands with more than $10 \%$ going to capital investment, therefore, all the other countries spend more than $90 \%$ of their available budgets in salaries and daily running of schools.

\section{Money buys teachers}

Current investment takes most of the money and teachers are thought to take the biggest slice. Nevertheless, data shows that this is not the case for most countries; 


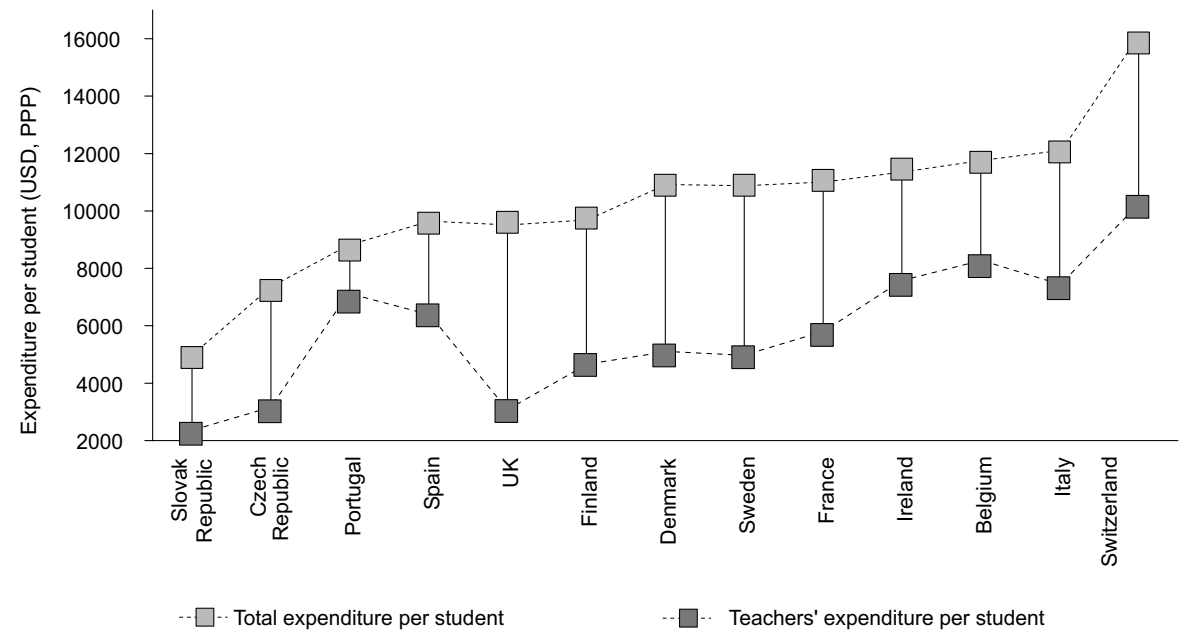

Figure 2 Relation between expenditure and teacher annual pay, per student

Source: OECD, Education at a Glance 2013.

only Portugal, Spain and Sweden spend more than $70 \%$ of their budgets paying teachers. In Switzerland a teacher costs over 10,000 USD per student while in the United Kingdom the cost is about 3000 USD. Does this represent poor pay or a better use of human resources? Why are there some countries with just about 1000 USD to spend on all other expenses, while some other countries manage to reserve more than 6000 USD per student? Is there a relation between the teacher cost per student and performance? What about teacher salary and performance?

To have a low expenditure per student does not mean an annual average low teachers' pay in every country. In fact, the United Kingdom spends about 3000 USD per student to pay for teacher's work, but teachers' salary is around 45,000 USD per year. The annual salary is similar to Belgium's though it has a per student cost of 8000 USD. Once again, Switzerland has the highest pay $(60,000$ USD) while Slovak Republic just pays 12,000 USD in line with the lowest cost per student.

The relation between teacher pay and PISA scores is mild. Despite a positive trend, this variable accounts for only $26 \%$ of the variance in results $\left(R^{2}=0.26\right.$ out of an univariable linear regression). Therefore I have turned my attention to the observation of countries that form groups according to these variables. Firstly, Poland and Czech Republic form a cluster where the students' score above 500, and teachers receive less than average. We can also identify a group where high pay is in line with high scores (Switzerland, Netherlands, Germany, Belgium, Finland, Denmark and Ireland). A third group with average pay and scores below the 500 milestone (Sweden, Italy, Norway, Portugal, Spain and the United Kingdom). Iceland, France, Slovenia form a group with average pay and average results. Finally, the cluster where very low paid teachers correspond to low scores (Hungary and Slovak Republic). 


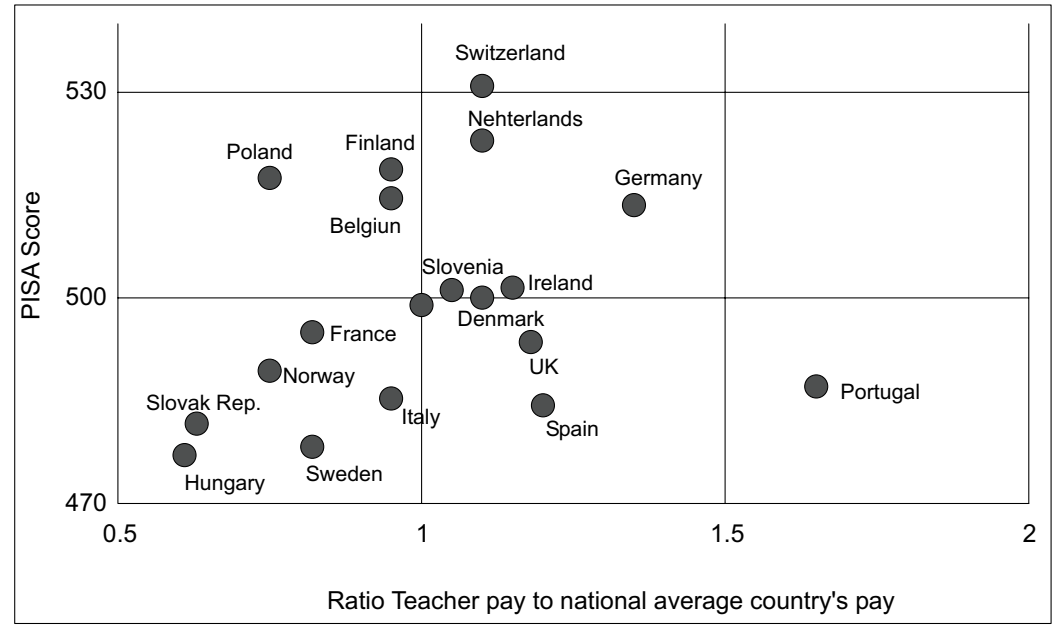

Figure 3 Ratio of teacher pay to national average pay on PISA's Math scores

Source: OECD, Education at a Glance 2013, and PISA 2012.

Another perspective is to compare teachers' pay with the national average pay, as a proxy of how well paid teachers feel, when compared to their fellow citizens.

The country where teachers have the highest relative pay is Portugal, where teachers receive $60 \%$ above national average, though their students do not achieve high scores. There is only a very weak link $\left(R^{2}=0.042\right)$ between relative pay and scores. Hungary, Norway, Sweden, Slovak Republic, France and Poland are countries where teachers receive less than the country's average. Math's results are all bellow 500, exception made to Poland.

The inexistence of relationship between teachers' pay and PISA scores shows that it is not payment that makes the difference, it does not increase the outcome of the systems. In the efficiency scale Poland, Slovenia and Czech Republic are the most efficient, while, Portugal, Spain, and United Kingdom are the least effective as the relative pay to teachers is high, and the results are below the 500 PISA points. There is no clear strategy to be adopted regarding teacher salaries. Further studies should be developed to understand the importance of salaries in quality. That question goes beyond the scope of this paper.

\section{Money buys class sizes and teaching hours}

Class size and the number of hours students receive of effective teaching is one of the big areas of immediate political intervention.

School has gained a full-time character to fulfil its social support role. As both parents have full-time jobs, children need to be cared for by schools.

These two variables should be analysed together as they reflect how to use teacher's lecturing hours - either work more hours in bigger groups or fewer 


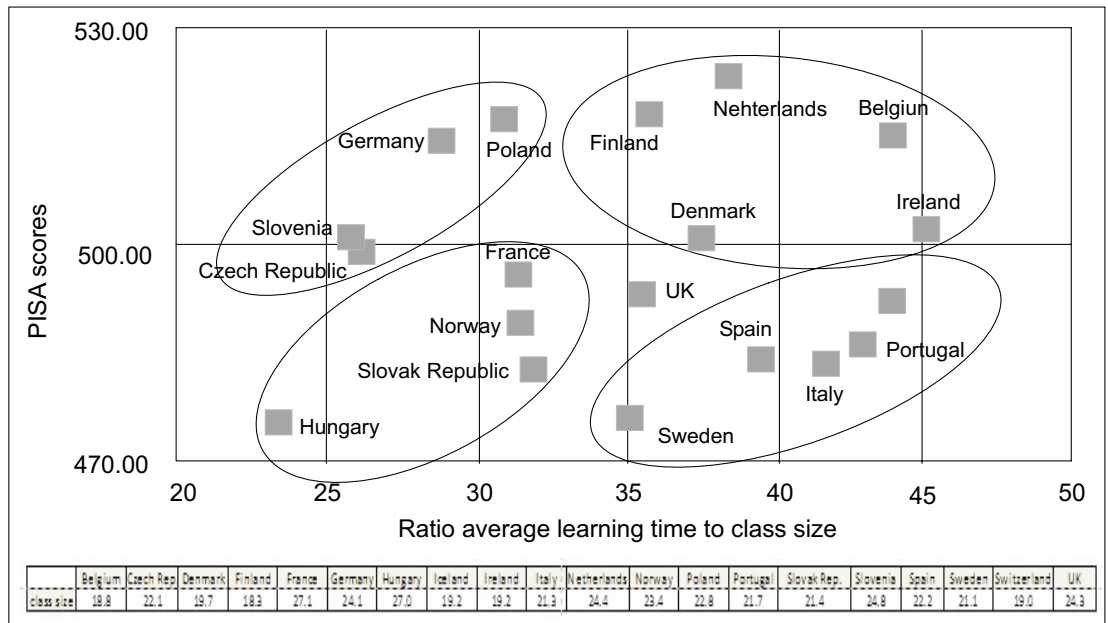

Figure 4 Ratio of annual learning time to class size (table) and PISA Math's Scores

Source: OECD, Education at a Glance 2013, and PISA 2012.

hours in smaller groups. Do students need many hours of taught classes, or would they perform better with less time being taught but in smaller groups with more opportunities for personalised attention?

As Sahlberg (2011) clarifies, fewer hours of schooling, less homework, more freedom is a pillar of Finnish success (Finland keeps students in school for about 24 hours per week). Obviously this is not the case with the countries under observation. Different choices seem to lead to similar results.

As can be clearly seen in figure 4 (table), not every country considers this trade-off: Finland, Denmark, Belgium and Iceland have a policy of small groups (less than 21 students per class), thought they have different strategies in terms of the number of teaching hours. On the opposite extreme, France and Hungary group the students in big classes and France opts for keeping students in school for long periods of time.

Figure 4 depicts the ratio of teaching hours to class size as the number of hours each student is entitled to as individual teacher attention.

Once again, there is no clear relation between individual teaching time and PISA scores. Clusters of strategies are visible on figure 4. Only the United Kingdom falls out of the groups as it falls in the middle of the scheme - the average number of hours of individual teaching time, and also about average results.

Spain, Italy, Portugal, Iceland and Sweden give students big opportunities for individual teaching, though they all perform below the 500 PISA standard average. With a similar strategy of teachers' time availability, but with above average scores countries like Netherlands, Finland, Belgium, Ireland and Denmark can be found. On the other hand, teachers' individual attention can be low, and results can still excel. This happens in countries such as Poland, Germany 


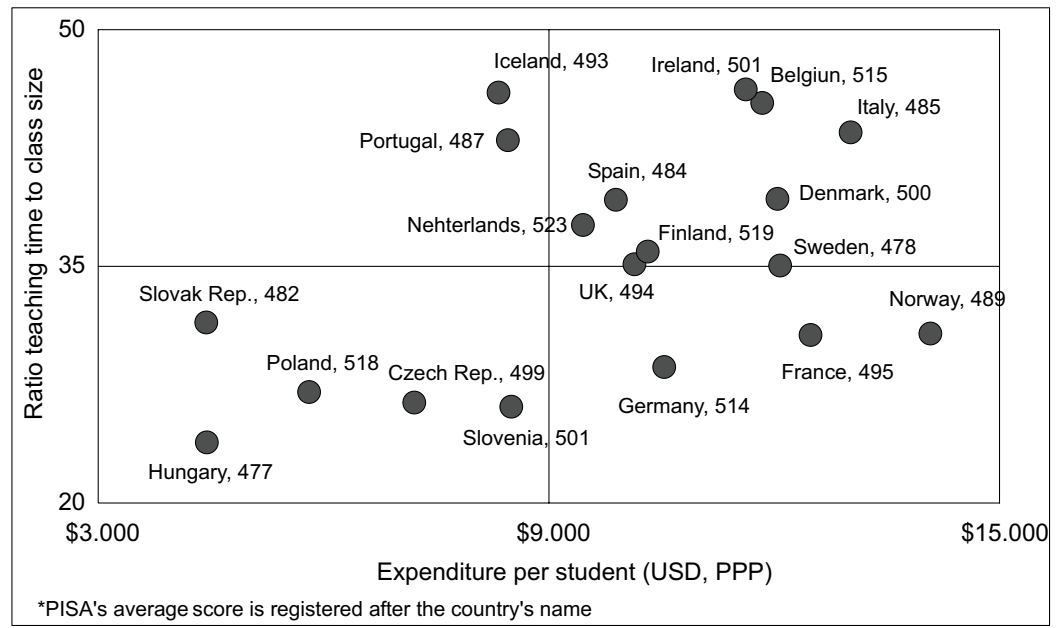

Figure 5 Expenditure per student and yearly individual teaching time

Source: OECD, Education at a Glance 2013, and PISA 2012.

and Slovenia. The last group comprises countries that are low achievers, but the teachers' time investment is also low - France, Norway, Slovak Republic and Hungary.

The old argument that there isn't enough money to increase the number of hours of individual attention is a fallacy. There is no direct relation between the expenditure per student and the number of hours of individual teaching. It is a political and management strategy, not financial.

It is not the amount of money, but the decision on where to spend it. Norway is a country with the highest expenditure but only 33 hours per year of individual teaching are available. On the range 10,000-12,000 USD expenditure per student we find all sorts of teacher availability. Germany has barely 30 hours per year, while Belgium presents its students with almost 45 hours.

Comparing yearly individual teaching time (calculated as the ratio between number of teaching hours received by students and class size) to PISA scores the most efficient countries are Poland and Germany. On the other hand, the most inefficient are Spain, Portugal and Italy.

\section{Money buys infrastructures and school resources}

Denmark, a country with the highest hourly payment, reserves $50 \%$ of its current budget for teachers' salary and the other half is parted among other staff and other expenses.

Czech Republic (similar to Portugal in terms of GDP and per student expenditure) spends $46.9 \%$ of its education budget on teachers' salary and $39 \%$ on other current expenses. Although teacher's hourly payment is low, they have clearly opted for 


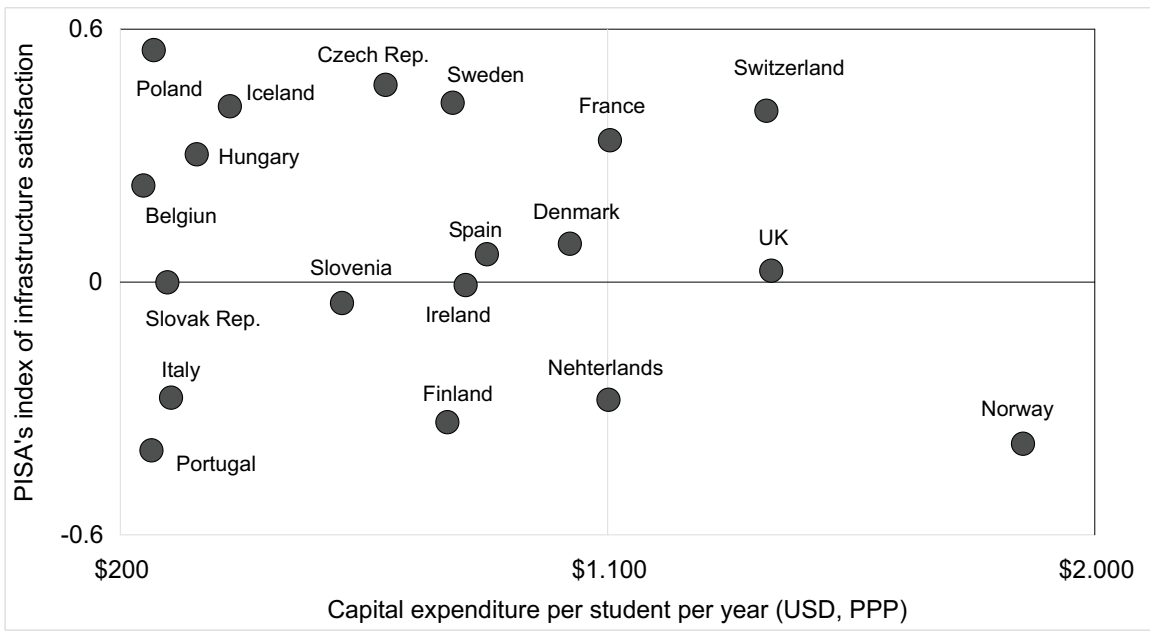

Figure 6 Capital expenditure per student per year on PISA's index Quality of Physical Infrastructure Source: OECD, Education at a Glance, 2013 and PISA 2012.

a different spending model. Portugal spends almost all its budget on teaching, being left with only $6 \%$ for capital investment (infrastructures and equipment).

In PISA 2012 school directors were asked about their perception of the quality of the infrastructure and also on the quality of resources available for teaching. This is not an absolute measure, but it measures the perceived impact of capital investments in the life of its users.

There are five countries where the directors think poorly of infrastructures Portugal, Norway, Netherlands, Finland and Italy. In this group, though, Portuguese and Dutch directors seem to be pleased with education resources. The happiest countries with infrastructures are Poland, Czech Republic and Sweden.

In relation to education resources Slovak Republic and Iceland are the most unhappy. Norwich and Finish directors are not also very pleased with educational resources.

We had already seen that countries spend different proportions of education expenditure in capital. Some countries are heavy investors in capital, investing around $15 \%$ of the education budget, and others leave virtually nothing to this type of investment.

Despite the spending strategy, there is no connection between perceived quality of infrastructures and the amount of money spent.

In Norway, where investment in infrastructure is about 1800 USD per year per student, school managers have very negative opinions. Collectively, they qualify infrastructures at the same level of countries like Portugal where very little investment is made (less than 300 USD per student per year).

On the opposite side Poland, with very little investment (about 300 USD) has very satisfied managers. 
Once again Poland is heading the group of the most efficient managers, small investment high levels of satisfaction. This group is also comprised by Czech Republic, Iceland, Hungary and Belgium.

Managing the infrastructure and the relation to expenditure level of satisfaction is efficient in many countries, as in most countries expenditure is relatively low and school directors are quite satisfied. Norway and the Netherlands are obviously the least efficient.

\section{Conclusion: an efficiency scale}

The final objective of this paper is to propose an efficiency scale based on the previous indicators.

The methodology for its development was by creating a table with all the variables described above and classify each country according to efficiency: Where countries with a higher score are least efficient, and not effective at all.

- One point - the country has an efficient behaviour in relation to the variable - achieves PISA scores above 500 at a relatively low cost.

- Two points - The country has an effective behaviour - achieves results above 500 Points at a relatively high cost.

- Three points - Does not achieve the desired results but the amount of resources spent is also low.

- Four points - Does not achieve the desired results but spends many resources.

In terms of global efficiency, it is possible to clearly identify the four groups.

Poland, Slovenia and Czech Republic are the most efficient countries, meaning PISA scores above average and directors' satisfaction towards infrastructures and resources were demonstrated in 2012. They are considered efficient as expense and general use of resources were low. They did better with lower resources. They are all ex-soviet allies where education is a strong social asset.

The second group, constituted by Germany, Belgium, Ireland, Switzerland, Denmark, Netherlands and Finland presented results above average but a lot of money was thrown into the system, though they are all countries with a high GDP per capita and a long tradition in educating their fellow citizens.

South and east poor European countries integrate the third group, where the United Kingdom emerges as the surprising exception. Results do not get to the desired level, though not enough resources are in the system, or the money is not being spent efficiently.

Finally, we have a group of just two countries who are very rich and spend much money on education though results are not reaching the desired levels Norway and Sweden. These countries should reconsider how they are spending the money and reallocate resources more efficiently. They are neither efficient nor effective. 


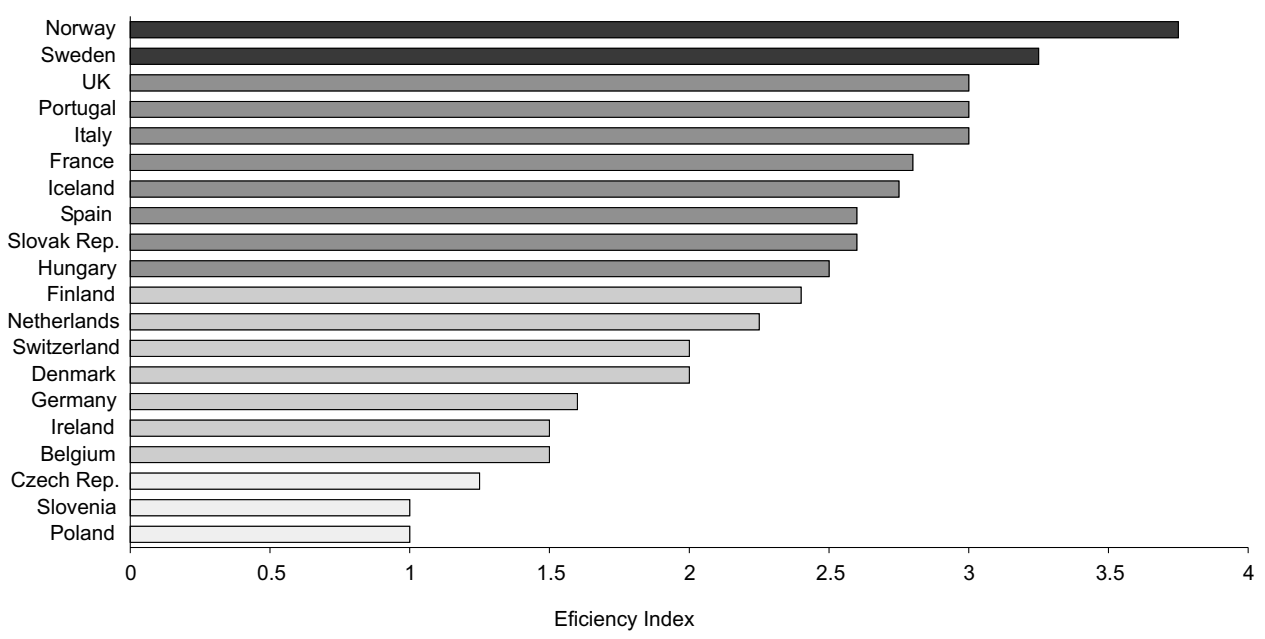

Figure 7 Aggregate efficiency scale

Source: OECD, Education at a Glance, 2013 and PISA 2012.

\section{References}

Afonso, A., and M. S. Aubyn (2005), Cross-Country Efficiency of Secondary Education Provision. A Semi-Parametric Analysis with Nondiscritionary Inputs, Frankfurt, European Central Bank, Working Paper Series No. 494, retrieved from: https://www.repository.utl.pt/bitstream/10400.5/2129/1/ecbwp494.pdf (last access August 2016).

Baker, Bruce D. (2012), Does Money Matter In Education?, Washington, DC, Albert Shanker Institute, retrieved from: http://files.eric.ed.gov/fulltext/ED528632.pdf (last access August 2016).

Coleman, J. S. (1967), "The concept of equality of educational opportunity”, Harvard Education Review, 38, pp. 7-22.

Dolton, P., O. Marcenaro-Gutiérrez, and A. Still (2014), The Efficiency Index - Which Education System Deliver the Best Value for Money?, London, GEMS Education Solutions, retrieved from: http://www.edefficiencyindex.com/book/ (last access August 2016).

Hanushek, E. A. (1986). “The economics of schooling: production and efficiency in the public schools", Journal of Economic Literature, 24 (3), pp. 1141-1178.

Hanushek, E. A. (2012), "Financing schools”, in J. Hattie and E. M. Anderman (Eds.), International Guide to Student Achievement, New York, Routledge.

Lemos, V. (2013), “Políticas públicas de educação: equidade e sucesso escolar", Sociologia, Problemas e Praticas, 73, pp. 151-159, DOI: 10.7458/SPP2013732812

Lockheed, M., and E. A. Hanushek (1994), “Concepts of educational efficiency and effectiveness", Human Resources Development and Operations Policy Working Papers, No. HRO 24, Washington, DC, World Bank. 
Martins, L., and P. Veiga (2010), “Do inequalities in parents' education play an important role in PISA students' mathematics achievement test score disparities?", Economics of Education Review, 29 (6), pp. 1016-1033, DOI: 10.1016/j.econedurev.2010.05.001

Mccluskey, N. (2004). "A lesson in waste where does all the federal education money go?", Policy Analysis, 518, pp. 1-32.

OECD (2013), Education at a Glance 2013. OECD Indicators, Paris, OECD Publishing, retrieved from: http://www.oecd-ilibrary.org/education/education-at-a-glance-2013_eag-2013-en (last access August 2016).

OECD (2014), “Do parents' occupations have an impact on student performance?", PISA in Focus, 2024/2 (February), pp. 1-4.

Rice, J., and E. Schwartz (2008), “Toward and understanding of procutivity in education", in H. F. Ladd and E. B. Fiske (Eds.), Handbook of Research in Education Finance and Policy, New York, Routledge.

Rodrigues, M. de L. (2012), "Os desafios da política de educação no século XXI”, Sociologia, Problemas e Práticas, 68, pp. 171-176, DOI: 10.7458/SPP201268698

Sahlberg, P. (2011), “Lessons from Finland”, American Educator, summer, pp. 34-38.

Wagstaff, A. (2011), A Hibrid Approach to Efficiency - Measuring with Empirical Illustrations from Education and Health, World Bank, Policy Research Working Paper, No. 5751.

Welch, A. R. (1998), “The cult of efficiency in education: comparative reflections on the reality and the rhetoric", Comparative Education, 34 (2), pp. 157-175, DOI: $10.1080 / 03050069828252$

Woessmann, L., and G. Schuetz (2006), Efficiency and Equity in European Education and Training Systems, Brussels, European Commission Education and Culture.

Isabel Flores. Estudante de doutoramento em Políticas Públicas, ISCTE-IUL, Av. das Forças Armadas, 1649-026 Lisboa.

E-mail: isabel_cristina_vieira_silva@iscte.pt

Receção: 2 de fevereiro de 2015 Aprovação: 6 de setembro de 2016 